\title{
Effect of cotton residues incorporation on soil properties, organic nitrogen fractions, and nitrogen-mineralizing enzyme activity under long-term continuous cotton cropping
}

\author{
Fangxia Ma ${ }^{1}$, Yiyun Wang ${ }^{1}$, Peng Yan $^{1}$, Fei Wei ${ }^{1}$, Zhiping Duan $^{1}$, Zhilan Yang ${ }^{1}$, Jianguo Liu ${ }^{\text {Corresp. } 1}$ \\ ${ }^{1}$ The Key Laboratory of Oasis Ecology Agriculture of Xinjiang Bingtuan, Shihezi University, Shihezi, Xinjiang, China \\ Corresponding Author: Jianguo Liu \\ Email address: I-jianguo@126.com
}

The objective of this experiment was to study the effect of cotton residues incorporation on soil properties, soil organic nitrogen $(\mathrm{N})$ fractions, and $\mathrm{N}$-mineralizing enzyme (protease, and urease) activity in the $0-40 \mathrm{~cm}$ soil layer in the long-term continuous cotton field. In this experiment, seven treatments, including cotton residues incorporation for 5, 10, 15 and 20 years (marked as 5a, 10a, 15a, and 20a) and continuous cropping for 5, 10 and 20 years (marked as CK5, CK10 and CK20) were conducted. The results showed that the soil organic carbon $(\mathrm{C})$ and $\mathrm{N}$ increased gradually with the increase in the duration of continuous cropping with cotton residues incorporation. Compared with CK20, the 20a treatments reduced the content of amino acid $N(A A N)$, ammonium $N(A N)$, amino sugar $N$ (ASN), hydrolysable unidentified N (HUN), and acid insoluble $N$ (AIN) significantly by 48.6 , $32.2,96.9,48.3$, and $38.7 \%$, respectively $(p<0.05)$. The activity of protease and urease in 20 a treatments significantly increased by 53.4 and $53.1 \%$ respectively as compared to CK20 ( $p<0.05)$. Soil organic $\mathrm{C}$ and $\mathrm{N}$-mineralizing enzyme activity decreased with the increase in cropping duration in the absence of cotton residues incorporation, while the organic $\mathrm{N}$ increased slightly. In conclusion, cotton residues returning can increase the storage of soil organic $\mathrm{C}$ and $\mathrm{N}$ in long-term continuous cropping cotton field, and improve the soil quality and soil fertility of continuous cropping cotton field. 
1 Effect of cotton residues incorporation on soil properties, organic nitrogen fractions, and nitrogen-mineralizing enzyme activity under long-term continuous cotton cropping

3 Fangxia Ma ${ }^{a}$, Yiyun Wang, Peng Yan, Fei Wei, Zhiping Duan, Zhilan Yang \& Jianguo Liu*

5 a The Key Laboratory of Oasis Ecology Agriculture of Xinjiang Bingtuan, Shihezi University,

6 Shihezi, Xinjiang, China.

*Corresponding author. E-mail: 1-jianguo@126.com

Running Head: cotton residues dose organic nitrogen and enzyme activity

21 Abstract 
22 The objective of this experiment was to study the effect of cotton residues incorporation on soil

23 properties, soil organic nitrogen $(\mathrm{N})$ fractions, and $\mathrm{N}$-mineralizing enzyme (protease, and urease)

24 activity in the $0-40 \mathrm{~cm}$ soil layer in the long-term continuous cotton field. In this experiment,

25 seven treatments, including cotton residues incorporation for 5, 10, 15 and 20 years (marked as

26 5a, 10a, 15a, and 20a) and continuous cropping for 5, 10 and 20 years (marked as CK5, CK10

27 and CK20) were conducted. The results showed that the soil organic carbon (C) and N increased

28 gradually with the increase in the duration of continuous cropping with cotton residues

29 incorporation. Compared with CK20, the 20a treatments reduced the content of amino acid N

30 (AAN), ammonium N (AN), amino sugar N (ASN), hydrolysable unidentified N (HUN), and

31 acid insoluble $\mathrm{N}(\mathrm{AIN})$ significantly by 48.6, 32.2, 96.9, 48.3, and 38.7\%, respectively $(\mathrm{p}<0.05)$.

32 The activity of protease and urease in 20 a treatments significantly increased by 53.4 and $53.1 \%$

33 respectively as compared to $\mathrm{CK} 20(\mathrm{p}<0.05)$. Soil organic $\mathrm{C}$ and $\mathrm{N}$-mineralizing enzyme activity

34 decreased with the increase in cropping duration in the absence of cotton residues incorporation,

35 while the organic $\mathrm{N}$ increased slightly. In conclusion, cotton residues returning can increase the

36 storage of soil organic $\mathrm{C}$ and $\mathrm{N}$ in long-term continuous cropping cotton field, and improve the

37 soil quality and soil fertility of continuous cropping cotton field.

38 Keywords: Cotton residues incorporation; organic N fractions; N-mineralizing enzymes;

39 continuous cotton cropping

40 Introduction

41 Nitrogen $(\mathrm{N})$ is an essential nutrient for crop growth and net primary productivity (Mulvaney,

42 2009). As over $90 \%$ soil $\mathrm{N}$ is existed in organic forms, soil $\mathrm{N}$ availability was primarily 
43 determined by soil organic carbon (C) and N (Stevenson, 1982). Crops primarily take up

44 inorganic $\mathrm{N}$ and can take in a small part of low molecular weight organic $\mathrm{N}$ under extreme

45 conditions (Ashton et al., 2010). Therefore, the mineralization of organic $\mathrm{N}$ is a critical

46 parameter regulating ecosystem productivity (Keuper et al., 2017).

47 The mineralization and depolymerization of organic $\mathrm{N}$ in the soil involves a sequence of 48 microbial enzymatic processes (Mengel, 1996). Most of the $\mathrm{N}$ input into the soil is in the form of 49 polymers, which must first be decomposed into smaller units by extracellular enzymes (Schimel 50 et al., 2004), which release small organic molecules that can then be directly absorbed or go on 51 degraded, $\mathrm{N}$ is absorbed in the form of ammonium $\left(\mathrm{NH}_{4}^{+}\right)$. Proteases are the most important 52 extracellular depolymerases for the hydrolysis of $\mathrm{N}$-containing molecules, and large proteins and 53 peptides can be hydrolyzed into peptides and amino acids, its activity is closely related to 54 microbial activity (Geisseler et al., 2008). Urease, which released ammonia from linear amides is 55 also an important depolymerase.

56 As an important source of soil organic matter (SOM), crop residues are rich in $\mathrm{C}, \mathrm{N}, \mathrm{P}, \mathrm{K}$, 57 and trace elements (Malhi et al., 2011). The incorporation of crop residues into the soil is an 58 important option for improving soil fertility. Bakht et al. (2009) found that crop residue 59 management increased soil $\mathrm{N}$, it helps maintain farmland fertility, and reduce fertilizer utilization.

60 Govaerts et al. (2007) also found that residue management improved soil microbial biomass and 61 catabolic diversity.

62 Xinjiang is the primary cotton cultivation region in China. The perennial, continuous 63 cropping of cotton and full incorporation of cotton residues into the field have become the 
64 primary means of organic fertilization in this region. Malhi et al. (2011) found that cotton

65 residues incorporation could increase the content of organic $\mathrm{N}$ under conventional and 66 conservational tillage conditions and could also reduce $\mathrm{N}$ losses through microbial $\mathrm{N}$

67 sequestration (Shan et al., 2013). However, little research has been done to elucidate the response

68 of soil organic $\mathrm{N}$ pools and $\mathrm{N}$-mineralizing enzyme activity for long-term continuous cropping

69 and cotton residues incorporation. The objective of this experiment was to study the effects of

70 cotton residues incorporation on soil properties, soil organic $\mathrm{N}$ fractions and the relationship

71 between soil organic $\mathrm{N}$ fractions and $\mathrm{N}$-mineralizing enzyme activity in a long-term continuous

72 cotton cropping system. We postulated that cotton residues incorporation contributes to the

73 increase in the storage of soil organic $\mathrm{C}$ and $\mathrm{N}$ in long-term continuous cropping cotton field.

74 Materials and methods

75 Study sites and experimental design

76 This experiment was conducted at a long-term continuous cropping experimental field at the

77 Shihezi University Agriculture College experimental station $\left(86^{\circ} 03^{\prime} \mathrm{E}, 45^{\circ} 19^{\prime} \mathrm{N}\right)$ situated in

78 Shihezi City, Xinjiang Uyghur Autonomous Region, China. The soil texture is gray desert soil,

79 and the basic soil properties are shown in Table 1.

80 There were seven treatments in the continuous cropping plots; four of which were cotton

81 residues incorporation treatments, the others were cotton residues removed treatments. There

82 were three replicates per treatment. The experimental design is single factor completely random

83 design. The duration of continuous cropping with cotton residues incorporation treatments

84 included 5, 10, 15, and 20 years, which were marked as 5a, 10a, 15a, and 20a, respectively. The

Peer] reviewing PDF | (2020:06:50331:2:0:NEW 29 Jan 2021) 
85

continuous cropping without residues incorporation treatments included 5, 10, and 20 years, which were marked as CK5, CK10, and CK20, respectively. The mode of cotton residues returning to the field for continuous cropping by cutting all the cotton residues into $5-8 \mathrm{~cm}$ with a guillotine after harvesting every autumn, namely, simulate the way of returning the cotton residues to the field mechanically, turn it into the plough layer before winter, and then irrigate it in the winter. The pattern of continuous cropping without cotton residues incorporation is to take all the cotton residues out of the field after harvesting, and then apply chemical fertilizer, ploughing, winter irrigation. The cotton was hand harvested. The average contents of C, N, P and $\mathrm{K}$ in cotton residues were about $41.3 \%, 1.69 \%, 0.43 \%$ and $3.14 \%$ (by dry weight), respectively. Nitrogen $300 \mathrm{~kg} \mathrm{hm}^{-2}$, phosphorus $\left(\mathrm{P}_{2} \mathrm{O}_{5}\right) 150 \mathrm{~kg} \mathrm{hm}^{-2}$, potassium $\left(\mathrm{K}_{2} \mathrm{O}\right) 75 \mathrm{~kg} \mathrm{hm}^{-2}, 30 \%$ of N fertilizer and $100 \%$ of phosphorus and potassium fertilizer were applied with tillage after cotton harvest. The other $70 \% \mathrm{~N}$ fertilizer was applied with water irrigating. The cultivar of cotton, Xinluzao 46, was sowed in April. On July, spraying growth regulator and manual topping are used to control excessive growth, prevent lodging, increase earliness, and decrease cotton bollworm infestations in cotton field. The way of planting was according to " $30+60+30 "$ configuration, using drip irrigation under mulch. The date of sowing was $20^{\text {th }}$ April, and spraying growth regulator and manual topping were on $10^{\text {th }}$ July every year. During the growth period, we would drip 11 times, the total drip was $5400 \mathrm{~m}^{3} \mathrm{hm}^{-2}$. Other field management followed the local practice.

\section{Soil sampling}

Soil samples in the 0-40 cm soil layer were collected in April 2017, five sampling points were 
106

107

108

109

110

111

112

113

114

115

116

117

118

119

120

121

122

123

124

125

126

combined to form one sample following the "S" shape in each experimental plot. After removing the visible plant roots and stones, the collected soil samples were mixed and passed through a 2 $\mathrm{mm}$ sieve. One portion of the samples were stored at $4{ }^{\circ} \mathrm{C}$ in order to measure the soil microbial biomass $\mathrm{C}\left(\mathrm{C}_{\text {mic }}\right), \mathrm{N}\left(\mathrm{N}_{\text {mic }}\right)$, and enzyme activity. The other soil samples were air dried and ground through a $0.149 \mathrm{~mm}$ sieve so as to determine the content of soil organic $\mathrm{C}$, total $\mathrm{C}$, total $\mathrm{N}$, and organic $\mathrm{N}$ fractions.

\section{Soil analyses}

Soil organic carbon (SOC) content was determined according to the method of Nelson et al. (1982). The content of total organic carbon $\left(\mathrm{C}_{\mathrm{tot}}\right)$ and total nitrogen $\left(\mathrm{N}_{\text {tot }}\right)$ in soil was measured by $\mathrm{K}_{2} \mathrm{Cr}_{2} \mathrm{O}_{7}$ oxidation method and Kjeldahl method. The Soil $\mathrm{C}_{\text {mic }}$ content and soil $\mathrm{N}_{\text {mic }}$ content were measured by chloroform fumigation extraction method (Joergensen, 1996).

\section{Soil organic $N$ fractions and $N$-mineralizing enzyme activities}

The fractions of organic $\mathrm{N}$ in soils were determined by hydrolyzing soil samples with $6 \mathrm{M} \mathrm{HCl}$ on an electric hot plate at $120^{\circ} \mathrm{C} \pm 3^{\circ} \mathrm{C}$ for $12 \mathrm{~h}$ (Bremner, 1965). The content of total hydrolysable $\mathrm{N}$, amino acid $\mathrm{N}$, and hydrolysable ammonium $\mathrm{N}$ was measured by the method of steam distillation. The equation (1) and (2) was used to calculate the content of hydrolysable unidentified $\mathrm{N}$ and acid insoluble $\mathrm{N}$, respectively. The activities of soil protease, and urease activities were measured by using colorimetrical methods. For the measurement of soil protease activity, $4 \mathrm{~g}$ of soil samples, $20 \mathrm{~mL} 20 \%$ casein solution, and $1 \mathrm{~mL}$ methylbenzene was added into $50 \mathrm{ml}$ glass triangular bottle and incubated for 24 hours at $30^{\circ} \mathrm{C}$. Then the solution was mixed with Sulfuric acid and sodium sulfate solutions to precipitate protein. After centrifuging, 
$1272 \mathrm{ml}$ of the supernatant and ninhydrin solution mixed in the water bath kettle at $100^{\circ} \mathrm{C}$ for 10

128 minutes and finally determined at $500 \mathrm{~nm}$. For the measurement of urease activity, $5 \mathrm{~g}$ of soil

129 samples and $1 \mathrm{ml}$ methylbenzene were added into $100 \mathrm{~mL}$ volumetric flask and incubated for 15

130 minutes, then $10 \mathrm{ml} 10 \%$ urea solution and $20 \mathrm{~mL}$ citrate buffer solution (pH 6.7) was added.

131 After the incubation for 24 hours, the $38^{\circ} \mathrm{C}$ of hot water was added to $100 \mathrm{~mL}$ scale line. Then

132 the $3 \mathrm{~mL}$ of filtered soil solution was mixed with distillated water, sodium phenoxide, and

133 sodium hypochlorite solution. After 20 minutes, the mixed soil solution was diluted to $50 \mathrm{~mL}$

134 and determined at $578 \mathrm{~nm}$.

135 Hydrolysable unidentified $\mathrm{N}=$ total hydrolysable $\mathrm{N}-\operatorname{amino}$ acid $\mathrm{N}-\operatorname{ammonium~} \mathrm{N}-\operatorname{amino}$

136 sugar $\mathrm{N}$

137

Acid insoluble $\mathrm{N}=$ soil total $\mathrm{N}$ - total hydrolysable $\mathrm{N}$

138

139

140

141

142

143

144

145

146

147

\section{Statistical analysis}

All data were related as means plus one standard deviation. One-way analysis of variance was used to examine the difference between treatments, and the significant difference was considered to reach the $\mathrm{p}<0.05$ level. Pearson correlation analysis was used for showing the relationship between soil organic $\mathrm{N}$ distribution and $\mathrm{N}$-mineralizing enzyme activities. All statistical analysis was carried out by SPSS 19.0.

\section{Results}

\section{Soil properties}

As shown in Table 2. The contents of $\mathrm{C}_{\text {mic }}, \mathrm{N}_{\text {mic }}$, SOC, $\mathrm{C}_{\text {tot }}$ and $\mathrm{N}_{\text {tot }}$ increased gradually with the increase in continuous cropping duration basically. All of these indexes peaked at 20 years. The 
$148 \mathrm{C}_{\text {mic }}$ of $20 \mathrm{a}$ increased $80.7 \%, 18.4 \%$, and $36.4 \%$, respectively, in comparison to $5 \mathrm{a}, 10 \mathrm{a}, 15 \mathrm{a}$;

$149 \mathrm{~N}_{\text {mic }}$ increased $92.1 \%, 20.9 \%$, and $37.2 \%$, respectively; $\mathrm{C}_{\text {tot }}$ increased $22.2 \%, 17.5 \%$, and $6.6 \%$,

150 respectively; $\mathrm{N}_{\text {tot }}$ increased $36.1 \%, 15.6 \%$, and $8.4 \%$, respectively; and SOC increased $44.7 \%$,

$151 \quad 13.6 \%$, and $16.5 \%$, respectively; all of which were significantly increased $(P<0.05)$. However,

$152(\mathrm{C}: \mathrm{N})_{\text {mic }}$ and $(\mathrm{C}: \mathrm{N})_{\text {tot }}$ tended to decrease with the increasing duration of continuous cropping, but

153 no significant difference was observed among treatments. The contents of $\mathrm{C}_{\text {mic }}, \mathrm{N}_{\text {mic }}, \mathrm{C}_{\text {tot }}$, $\mathrm{SOC}$,

154 and $(\mathrm{C}: \mathrm{N})_{\text {tot }}$ decreased with the increase in continuous cropping duration, while the contents of

$155 \mathrm{~N}_{\text {tot }}$ and $(\mathrm{C}: \mathrm{N})_{\text {mic }}$ increased.

156 Compared with the treatments without cotton residues incorporation, the content of $\mathrm{C}_{\text {mic }}$,

$157 \mathrm{~N}_{\text {mic }}, \mathrm{SOC}, \mathrm{C}_{\text {tot }}$ and $\mathrm{N}_{\text {tot }}$ in the treatments with cotton residues incorporation was significantly

158 higher. Compared with CK5, CK10, and CK20, $\mathrm{C}_{\text {mic }}$ increased 4.2\%, 65.3\%, and 125.1\%, $\mathrm{N}_{\text {mic }}$

159 increased $3.8 \%, 73.6 \%$, and $146.7 \%$, SOC increased $10.6 \%, 49.5 \%$, and $95.9 \%$ in $5 \mathrm{a}$, 10a, and

$16020 \mathrm{a}$, respectively, and with the exception of 5a, these values were all significant $(P<0.05)$.

161 Additionally, the content of $\mathrm{C}_{\text {tot }}$ increased $17.4 \%, 24.1 \%$, and $62.8 \%$, and that of $\mathrm{N}_{\text {tot }}$ increased

$16226.7 \%, 39.4 \%$, and $44.4 \%$, respectively $(P<0.05)$. Cotton residues incorporation thus had no

163 significant effect on $(\mathrm{C}: \mathrm{N})_{\text {mic }}$ and $(\mathrm{C}: \mathrm{N})_{\text {tot }}$.

164 Soil organic N fractions

165 The contents of different fractions of soil organic $\mathrm{N}$ are shown in Table 3 . Under the condition

166 of cotton residues incorporation, amino acid $\mathrm{N}$ and amino sugar $\mathrm{N}$, ammonium $\mathrm{N}$, hydrolysable

unidentified $\mathrm{N}$, and acid-insoluble $\mathrm{N}$ increased gradually with increased continuous cropping

basically. All of these indexes reached their maximum value after 20 years of continuous 
169

170

171

172

173

174

175

176

177

178

179

180

181

182

183

184

185

186

187

188

189

cropping. In $5 \mathrm{a}, 10 \mathrm{a}$, and $15 \mathrm{a}$, the amino acid $\mathrm{N}$ content at 20 years of continuous cropping increased $52.9 \%, 13.0 \%$, and $23.8 \%$, respectively; ammonium $\mathrm{N}$ increased $34.5 \%, 16.4 \%$, and $8.3 \%$, respectively; amino sugar $\mathrm{N}$ increased $42.2 \%, 11.3 \%$, and $21.9 \%$, respectively; hydrolysable unidentified $\mathrm{N}$ and acid-insoluble $\mathrm{N}$ increased $32.1 \%, 15.1 \%,-3.8 \%$, and $28.9 \%$, $18.4 \%$, and $8.7 \%$, respectively. The difference between treatments were significant $(P<0.05)$. In the absence of cotton residues incorporation, amino acid $\mathrm{N}$ and ammonium $\mathrm{N}$. Hydrolysable unidentified $\mathrm{N}$ and acid-insoluble $\mathrm{N}$ also increased with the increase in continuous cropping duration, but amino sugar $\mathrm{N}$ decreased gradually, the difference was not significant. Amino acid $\mathrm{N}$, ammonium $\mathrm{N}$, amino sugar $\mathrm{N}$, hydrolysable unidentified $\mathrm{N}$, and acid-insoluble $\mathrm{N}$ in the treatment with cotton residues incorporation were significantly higher than that of the treatment without cotton residues incorporation. Compared with CK5, CK10, and CK20, the amino acid N of $5 \mathrm{a}, 10 \mathrm{a}$, and $20 \mathrm{a}$ increased $26.87 \%, 53.33 \%$, and $48.57 \%$; ammonium $\mathrm{N}$ increased $8.7 \%, 7.7 \%$, and 28.6\%; amino sugar $\mathrm{N}$ increased $11.1 \%, 53.3 \%$, and $96.9 \%$; hydrolysable unidentified $\mathrm{N}$ increased $32.4 \%, 43.9 \%$, and $48.3 \%$; and acid-insoluble $\mathrm{N}$ increased $29.5 \%, 34.5 \%$, and $38.8 \%$, respectively.

The ratio of amino acid $\mathrm{N}$ to total $\mathrm{N}$ was $19.5 \%-22.4 \%$; ammonium $\mathrm{N}$ was $16.3 \%-18.7 \%$; amino sugar $\mathrm{N}$ was $4.0 \%-5.9 \%$ (Fig. 1); hydrolysable unidentified $\mathrm{N}$ was $25.7 \%-29.8 \%$; and acid-insoluble $\mathrm{N}$ was $29.2 \%-31.5 \%$, respectively. The organic $\mathrm{N}$ fractions were in the following order: acid-insoluble $\mathrm{N}>$ hydrolysable unidentified $\mathrm{N}>$ amino $\operatorname{acid} \mathrm{N}>\operatorname{ammonium} \mathrm{N}>\operatorname{amino}$ sugar $\mathrm{N}$. The proportion of amino acid $\mathrm{N}$, acid sugar $\mathrm{N}$, and hydrolysable acid $\mathrm{N}$ under cotton residues incorporation increased compared with the treatment lacking cotton residues. Compared 
190

191

192

193

194

195

196

197

198

199

200

201

202

203

204

205

206

207

208

209

210

with CK5, CK10, and CK20, the proportion of amino acid $\mathrm{N}$ increased $0.1 \%, 10.0 \%$, and 2.9\%; acid sugar $\mathrm{N}$ increased $-12.3 \%, 10.0 \%$ and $36.3 \%$; and the proportion of hydrolysable unidentified $\mathrm{N}$ increased $4.5 \%, 3.3 \%$, and $2.7 \%$, respectively, under continuous cropping for 5 , 10, and 20 years. In contrast, the proportion of ammonium $\mathrm{N}$ and acid-insoluble $\mathrm{N}$ decreased $6.6 \%, 12.6 \%$, and $8.5 \%$ and $-2.3 \%, 3.45 \%$, and $3.9 \%$, respectively, for 5,10 , and 20 years of continuous cropping, compared with CK5, CK10, and CK20. The proportion of amino acid N increased, but the proportion of acid-insoluble $\mathrm{N}$ decreased with the increase in continuous cropping duration.

\section{Soil N-mineralizing enzyme activities}

As shown in Fig. 2 and Fig. 3, the protease and urease showed an increasing trend with the increase in cropping duration under the cotton residues incorporation treatment, with values of $18.6 \mu \mathrm{g} \mathrm{g}^{-1}$ and $550.3 \mu \mathrm{g} \mathrm{g}^{-1}$, respectively, for 20 years of continuous cropping. Compared with continuous cropping for $5 \mathrm{a}, 10 \mathrm{a}$, and $15 \mathrm{a}$, the protease activities of continuous cropping for 20 years increased significantly $(P<0.05) 34.2 \%, 22.5 \%$, and $26.3 \%$, respectively. Urease contents under continuous cropping increased $15.5 \%, 2.7 \%$, and 1.6\%, respectively, and the 5-year treatment showed a significant difference. The activities of the two enzymes all showed a decreasing trend with the increase in continuous cropping duration in the absence of cotton residues incorporation. The enzyme activities under cotton residues incorporation were significantly higher in comparison for the same continuous cropping treatment durations. Compared with CK5, CK10, and CK20, protease activity under continuous cropping for 5a, 10a, and $20 \mathrm{a}$ increased $11.8 \%, 30.4 \%$, and $53.4 \%$, respectively; urease increased $10.3 \%, 37.6 \%$, and 
$21153.1 \%$, respectively.

212 Relationship between soil organic $N$ fractions and $N$-mineralizing enzyme activities

213 The total organic $\mathrm{N}$ and proportion of ammonium $\mathrm{N}$ showed significant positive and negative

214 correlations with all N-mineralizing enzymes (protease, urease) $(P<0.05)$ (Table 4). The

215 proportion of amino acid $\mathrm{N}$, amino sugar $\mathrm{N}$, and hydrolyzed unidentified $\mathrm{N}$ were positively

216 correlated with all the $\mathrm{N}$-mineralizing enzymes, while acid-insoluble $\mathrm{N}$ was negatively correlated.

\section{Discussion}

218 Effect of cotton residues incorporation on soil properties and organic $\mathbf{N}$ fractions

219 The previous study showed that the content of soil total C, N, and SOC in the cotton residues incorporation treatments increased with the duration of continuous cotton cropping increased, and our finding are consistent with $\mathrm{Yu}$ et al. (2020). On the contrary, in the treatments that the cotton residues were not incorporated into field, the content of soil total $\mathrm{C}$ and SOC decreased with the increasing duration of continuous cotton cropping. This is mainly due to the high organic $\mathrm{C}$ content in the cotton residues, which provides exogenous organic matter to the soil and partly enters the soil during microbial decomposition, thus increasing the soil organic $\mathrm{C}$ content

(Xu et al., 2011). Secondly, because of the high organic C content of the cotton residues, under a high $\mathrm{C}: \mathrm{N}$ ratio, microorganisms need to absorb more inorganic $\mathrm{N}$ from the soil to satisfy their growth requirements, thus improving the ability of microorganisms to utilize ammonium $\mathrm{N}$ and nitrate N (Ren et al., 2016). Microorganisms are required for the assimilation of more available

$\mathrm{N}$ into the soil organic $\mathrm{N}$ pool (Tian et al., 2017). Cotton residues incorporation increased the content of $\mathrm{C}$ and $\mathrm{N}$ in the soil, which indicated the $\mathrm{N}$ in the cotton residues incorporation 
232 treatment were significantly higher than that lacking cotton residues, which may be due to the 233 increase in soil microbial biomass caused by cotton residues incorporation and the improved soil 234 microbial structure. As the structural index of soil microbial community, the $(\mathrm{C}: \mathrm{N})_{\text {mic }}$ ratio is 235 used to describe the relative contribution of bacteria and fungi to the soil microbial community, a 236 higher $(\mathrm{C}: \mathrm{N})_{\text {mic }}$ ratio indicates that the proportion of fungi in the soil microbial community is 237 higher. The lower $(\mathrm{C}: \mathrm{N})_{\text {mic }}$ ratio indicates that the proportion of bacteria is higher (Tian et al., 2017). In this study, the $(\mathrm{C}: \mathrm{N})_{\text {mic }}$ ratio decreased gradually with the increased in continuous cropping duration under cotton residues incorporation treatments, while the opposite was observed in the treatments that the cotton residues were not incorporated. The results showed that the number of bacteria in the soil increased gradually with the increase in continuous cropping duration under cotton residues incorporation, which will be beneficial to the development of the cotton field soil in a good direction.

This study also found that cotton residues incorporation increased the content of acid-

hydrolyzed ammonium $\mathrm{N}$, and the content increased gradually with the increase in continuous cropping duration. As an important component of soil organic $\mathrm{N}$ decomposition, ammonium $\mathrm{N}$ also partly originates from soil-fixed $\mathrm{NH}_{4}{ }^{+}$, which constitutes a rapidly released and available soil N pool for plants and microorganisms (Lü et al., 2013). The decrease in the proportion of ammonium $\mathrm{N}$ to total $\mathrm{N}$ under cotton residues incorporation could be attributed to the increased fixation or uptake of mineral $\mathrm{N}$ by microorganisms and plants. The acid-insoluble $\mathrm{N}$ measured by Bremner's method is in the form of heterocyclic $\mathrm{N}$ or a combination of a heterocyclic compound with an aromatic compound. Heterocyclic compounds and aromatic compounds are 
253 stable $\mathrm{N}$ compounds. Stable organic $\mathrm{N}$ is difficult to be mineralized, leading to its accumulation

254 in the soil (Tian et al., 2017). Secondly, acid-insoluble N is considered as the structural

255 component of humus, and its main source is the senescent substances in aboveground and

256 underground debris (Ren et al., 2016). This can be explained by the increase in humus content in

257 the soil following cotton residues incorporation, leading to the increase in acid-insoluble $\mathrm{N}$

258 content.

259

260

261

262

263

264

265

266

267

268

269

270

271

272

273

\section{Effect of cotton residues incorporation on potential $\mathrm{N}$-mineralizing enzyme activities}

Enzymes mainly originate from soil microorganisms and plant secretions in the soil and are the main catalyst of all biochemical processes in the soil. Enzyme activity not only reflects soil quality, but also reflects the direction and intensity of biochemical reactions in the soil (He et al., 2020). It is considered as a sensitive index of soil system change because of the responsiveness, rapid determination, specificity, and comprehensiveness of soil enzymes. Our study showed that cotton residues incorporation could increase the soil urease and protease activities, which was due to the increase in soil urease and protease activities, which was due to the increase in soil microbial $\mathrm{C}$ under cotton residues incorporation treatments. On the contrary, the soil microbial $\mathrm{C}$ decreased gradually with the increasing duration of continuous cropping when the cotton residues were not incorporated, leading to the decreased soil enzyme activity.

\section{Potential mechanisms involved in soil organic $\mathbf{N}$ turnover under the condition of cotton} residues incorporation

72 The transformation and absorption of soil $\mathrm{N}$ is conducted by enzyme systems, and their synthesis and expression require $\mathrm{C}, \mathrm{N}$, and energy, suggesting that the form of available $\mathrm{N}$, the source of $\mathrm{C}$, 
274 and the $\mathrm{C}$ availability in relation to $\mathrm{N}$ are important factors (Yang et al., 2016). It is generally

275 believed that all organic $\mathrm{N}$ is mineralized to $\mathrm{NH}_{4}^{+}$before being absorbed by soil microorganisms.

276 This pathway is generally known as the mineralization-immobilization-turnover (MIT) route.

277 When the concentration of $\mathrm{NH}_{4}{ }^{+}$was relatively high (Figure S1), the gene transcription of the enzyme systems needed to replace the $\mathrm{N}$ source were inhibited, and cell $\mathrm{N}$-mineralizing enzymes were involved in the potential transformation of soil organic $\mathrm{N}$ under the condition of cotton residues incorporation, enzymatic mineralization is superior to the direct route (Tian et al., 2017). Under C-limited conditions, the substrates of $\mathrm{N}$ with low molecular weights, such as amino acids and amino sugars, can be directly absorbed by microorganisms as a C source (Nannipieri \& Eldor, 2009). There were significant positive correlations between soil total organic N and Nmineralizing enzyme activities, indicating that the activities of $\mathrm{N}$-mineralizing enzymes in the soil played an active role in the potential transformation of soil organic N. However, there was no significant positive correlation between the ratios of amino acid $\mathrm{N}$, amino sugar $\mathrm{N}$, and acidhydrolyzed unknown $\mathrm{N}$ and the activity of $\mathrm{N}$-mineralizing enzymes, which was due to the fact that the transformation of soil organic $\mathrm{N}$ was restricted by the lack of $\mathrm{C}$ source. But the ratio of ammonia $\mathrm{N}$ showed a significant negative correlation with the activity of $\mathrm{N}$-mineralizing enzymes. This is because the increased soil $\mathrm{N}$-mineralizing enzymes after cotton residues incorporation promoted the mineralization of soil organic $\mathrm{N}$.

In the cotton residues incorporation treatments, the decrease of the proportion was attributed to the increase of fixation or absorption of mineral $\mathrm{N}$ by microorganisms and plants. Therefore, in the soil of long-term continuous cropping cotton field, soil microorganisms need to absorb 
295

296

297

298

299

300

301

302

303

304

305

306

307

308

309

310

311

312

313

314

315

organic $\mathrm{N}$ molecules to meet the demand for $\mathrm{C}$ due to cotton residues incorporation.

\section{Conclusions}

Cotton residues incorporation was beneficial to improve soil quality and soil fertility in the longterm continuous cotton cropping field. The benefits can be increased over time. Under the condition of cotton residues incorporation, when the concentration of $\mathrm{NH}_{4}{ }^{+}$was high, enzymatic mineralization constituted the main pathway of potential organic $\mathrm{N}$ turnover. However, when cotton residues were not incorporated into the soil, the utilization of soil organic $\mathrm{N}$ was the most direct route due to the lower soil organic $\mathrm{C}$ availability.

\section{Acknowledgements}

This study is supported by the National Natural Science Foundation of China (31960396, 31560375).

\section{References}

Ashton IW, Miller AE, Bowman WD, Suding KN. 2010. Niche complementarity due to plasticity in resource use: plant partitioning of chemical N forms. Ecology 91: 3252-3260.

Bakht J, Shafi M, Jan MT. 2009. Influence of crop residue management, cropping system and $\mathrm{N}$ fertilizer on soil $\mathrm{N}$ and $\mathrm{C}$ dynamics and sustainable wheat production. Soil \& Tillage Research 104: 233-240.

Bremner JM. 1965. Organic forms of nitrogen//Black C A, ed. Methods of soil analysis. Madison: American Society of Agronomy, pp: 1238-1255. 
316 Geisseler D. 2008. Horwath W R. Regulation of extracellular protease activity in soil in

317

318

319

320

321

322

323

324

325

326

327

328

329

330

331

332

333

334

335

336

response to different sources and concentrations of nitrogen and carbon. Soil Biology \& Biochemistry 40: 3040-3048.

Gentile R, Vanlauwe B, Chivenge P. 2011. Trade-offs between the short- and long-term effects of residue quality on soil C and N dynamics. Plant \& Soil 338: 159-169.

Gonzalez-Prieto SJ, Carballas T. 1991. Composition of organic N in temperate humid region soils. Soil Biology \& Biochemistry 23: 887-895.

González-prieto SJ, Jocteurmonrozier L, Hétier JM. 1997. Changes in the soil organic N fractions of a tropical Alfisol fertilized with $15 \mathrm{~N}$-urea and cropped to maize or pasture. Plant \& Soil 195: 151-160.

Govaerts B, Mezzalama M, Unno Y. 2007. Influence of tillage, residue management, and crop rotation on soil microbial biomass and catabolic diversity. Applied Soil Ecology 37: 18-30.

He WY, Zhang MM, Jin GZ, Sui X, Zhang T, Song FQ. 2020. Effects of nitrogen deposition on nitrogen-mineralizing enzyme activity and soil microbial community structure in a korean pine plantation. Microbial Ecology. DOI: https://doi.org/10.1007/s00248-020-015956.

Jezierskatys S, Frac M. 2009. Impact of dairy sewage sludge on enzymatic activity and inorganic nitrogen concentrations in the soils. International Agrophysics 23: 31-37.

Joergensen RG. 1996. The fumigation-extraction method to estimate soil microbial biomass: Calibration of the k EC, value. Soil Biology \& Biochemistry 28: 25-31.

Keuper F, Dorrepaal E, Van Bodegom PM, Van Logtestijn R, Venhuizen G, Van Hal J, 
337

338

339

340

341

342

343

344

345

346

347

348

349

350

351

352

353

354

355

356

357

Aerts R. 2017. Experimentally increased nutrient availability at the permafrost thaw front selectively enhances biomass production of deep-rooting subarctic peatland species. Global Change Biology 23: 4257-4266.

Kielland K, Mcfarland JW, Ruess RW. 2007. Rapid Cycling of Organic Nitrogen in Taiga Forest Ecosystems. Ecosystems 10: 360-368.

Kwon HY, Hudson RJM, Mulvaney RL. 2009. Characterization of the organic nitrogen fraction determined by the Illinois soil nitrogen test. Soil Science Society of America Journal 73: 1033-1043.

Lü H, He H, Zhao J. 2013. Dynamics of fertilizer-derived organic nitrogen fractions in an arable soil during a growing season. Plant \& Soil 373: 595-607.

Malhi SS, Nyborg M, Solberg ED. 2011. Improving crop yield and N uptake with long-term straw retention in two contrasting soil types. Field Crops Research 124: 378-391.

Malhi SS, Nyborg M, Solberg ED. 2011. Long-term straw management and N fertilizer rate effects on quantity and quality of organic $\mathrm{C}$ and $\mathrm{N}$ and some chemical properties in two contrasting soils in Western Canada. Biology \& Fertility of Soils 47: 785-800.

Mengel K. 1996. Turnover of organic nitrogen in soils and its availability to crops. Plant \& Soil 181: 83-93.

Mulvaney RL, Khan SA, Ellsworth TR. 2009. Synthetic Nitrogen Fertilizers Deplete Soil Nitrogen: A Global Dilemma for Sustainable Cereal Production. Journal of Environmental Quality 38: 2295-2314.

Nannipieri P, Eldor P. 2009. The chemical and functional characterization of soil $\mathrm{N}$ and its 
biotic components. Soil Biology \& Biochemistry 41: 2357-2369.

Nelson DW, Sommers LE. 1982. Total carbon, organic carbon, and organic matter. In: Page AL (ed) Methods of soil analysis. Part 2. Chemical and microbiological properties. Soil Science Society of America pp: 539-579.

Ren CJ, Sun PS, Kang D, Zhao FZ, Feng YZ, Ren GX, Han XH, Yang GH. 2016. Responsiveness of soil nitrogen fractions and bacterial communities to afforestation in the loess hilly region (lhr) of china. Scientific Reports, 6: 28469.

Schimel JP, Bennett J. 2004. Nitrogen mineralization: challenges of a changing paradigm. Ecology, 85: 591-602.

Shan J, Yan X. 2013. Effects of crop residue returning on nitrous oxide emissions in agricultural soils. Atmospheric Environment, 71: 170-175.

Stevenson FJ. 1982. Organic forms of soil nitrogen. In: Stevenson FJ (ed) Nitrogen in Agriculture Soil. ASA-CSSA-SSSA, Madison, pp 67-122

Tian J, Wei K, Condron LM. 2017. Effects of elevated nitrogen and precipitation on soil organic nitrogen fractions and nitrogen-mineralizing enzymes in semi-arid steppe and abandoned cropland. Plant \& Soil 1-13.

Xu M, Lou Y, Sun, X. 2011. Soil organic carbon active fractions as early indicators for total carbon change under straw incorporation. Biology \& Fertility of Soils 47: 745.

Yan D, Wang D, Yang L. 2007. Long-term effect of chemical fertilizer, straw, and manure on labile organic matter fractions in a paddy soil. Biology \& Fertility of Soils 44: 93-101.

Yang L, Zhang L, Geisseler D. 2016. Available $\mathrm{C}$ and $\mathrm{N}$ affect the utilization of glycine by soil 
$379 \quad$ microorganisms. Geoderma 283: 32-38.

380 Yu QG, Hu X, Ma JW, Ye J, Sun WC, Wang Q, Lin H. 2020. Effects of long-term organic 381 material applications on soil carbon and nitrogen fractions in paddy fields. Soil and Tillage 382 Research, 196: 104483. 


\section{Table $\mathbf{1}$ (on next page)}

Basic soil properties at experimental site. 
1

\begin{tabular}{|c|c|c|c|c|c|c|}
\hline $\begin{array}{l}\text { Duration } \\
\text { (a) }\end{array}$ & $\begin{array}{l}\frac{\text { Bulk }}{\text { density }} \\
\underline{\left(\mathrm{g} \mathrm{cm}^{-3}\right)} \\
\end{array}$ & $\underline{\mathrm{pH}}$ & $\begin{array}{c}\text { Organic matter } \\
\qquad\left(\mathrm{g} \cdot \mathrm{kg}^{-1}\right)\end{array}$ & $\begin{array}{c}\text { Alkali-hydrolyzable } \\
\begin{array}{c}\text { nitrogen } \\
\left(\mathrm{mg} \cdot \mathrm{kg}^{-1}\right)\end{array} \\
\end{array}$ & $\begin{array}{c}\begin{array}{c}\text { Available } \\
\text { phosphorus }\end{array} \\
\left(\mathrm{mg} \cdot \mathrm{kg}^{-1}\right) \\
\end{array}$ & $\begin{array}{c}\text { Available potassium } \\
\left(\mathrm{mg} \cdot \mathrm{kg}^{-1}\right)\end{array}$ \\
\hline$\underline{5}$ & $\underline{1.37}$ & $\underline{7.31}$ & $\underline{15.28}$ & $\underline{70.84}$ & $\underline{40.8}$ & $\underline{183}$ \\
\hline$\underline{10}$ & $\underline{1.38}$ & $\underline{7.24}$ & $\underline{16.32}$ & $\underline{74.36}$ & 23.1 & $\underline{110.3}$ \\
\hline$\underline{15}$ & $\underline{1.35}$ & $\underline{7.35}$ & $\underline{17.98}$ & $\underline{84.06}$ & 25.4 & $\underline{65.5}$ \\
\hline$\underline{20}$ & $\underline{1.33}$ & 7.26 & $\underline{18.51}$ & $\underline{89.08}$ & $\underline{20.1}$ & $\underline{72.3}$ \\
\hline$\underline{\mathrm{CK} 5}$ & 1.31 & $\underline{7.29}$ & $\underline{14.35}$ & $\underline{113.1}$ & $\underline{36.47}$ & 125.4 \\
\hline CK10 & 1.36 & $\underline{7.33}$ & $\underline{15.67}$ & $\underline{98.75}$ & $\underline{46.28}$ & 112.8 \\
\hline CK20 & 1.34 & 7.37 & 15.22 & 109.4 & 40.34 & 108.5 \\
\hline
\end{tabular}
2

3

4 


\section{Table 2 (on next page)}

Changes of soil properties in $0-40 \mathrm{~cm}$ soil depth after long-term continuous croppingand cotton residues incorporation. 
1

\begin{tabular}{cccccccc}
\hline Treatment & $\begin{array}{c}\mathrm{C}_{\text {mic }} \\
\mathrm{mg} \mathrm{kg}^{-1}\end{array}$ & $\mathrm{~N}_{\text {mic }}$ & $\begin{array}{c}\mathrm{C}_{\text {tot }} \\
\mathrm{g} \mathrm{kg}^{-1}\end{array}$ & $\mathrm{~N}_{\text {tot }}$ & $\mathrm{SOC}$ & $(\mathrm{C}: \mathrm{N})_{\text {mic }}$ & $(\mathrm{C}: \mathrm{N})_{\text {tot }}$ \\
& $83.88 \pm 5.21 \mathbf{d}$ & $18.5 \pm 0.83 \mathbf{d}$ & $10.25 \pm 0.79 \mathbf{c}$ & $0.51 \pm 0.02 \mathbf{d}$ & $3.44 \pm 0.51 \mathbf{c}$ & $4.57 \pm 0.36 \mathbf{a b}$ & $20.21 \pm 3.21 \mathbf{a}$ \\
\hline $5 \mathrm{a}$ & $127.54 \pm 8.35 \mathbf{b}$ & $29.41 \pm 2.61 \mathbf{b}$ & $10.66 \pm 3.51 \mathbf{c}$ & $0.60 \pm 0.02 \mathbf{c}$ & $4.38 \pm 0.67 \mathbf{b}$ & $4.36 \pm 0.78 \mathbf{a b}$ & $17.87 \pm 3.71 \mathbf{b}$ \\
$10 \mathrm{a}$ & $110.75 \pm 8.26 \mathbf{c}$ & $25.9 \pm 4.48 \mathbf{c}$ & $11.75 \pm 3.67 \mathbf{b}$ & $0.64 \pm 0.03 \mathbf{b}$ & $4.27 \pm 1.02 \mathbf{b}$ & $4.29 \pm 1.15 \mathbf{a b}$ & $18.48 \pm 2.57 \mathbf{a}$ \\
$15 \mathrm{a}$ & $151.04 \pm 10.38 \mathbf{a}$ & $35.55 \pm 6.50 \mathbf{a}$ & $12.52 \pm 2.16 \mathbf{a}$ & $0.69 \pm 0.02 \mathbf{a}$ & $4.98 \pm 0.77 \mathbf{a}$ & $4.19 \pm 0.22 \mathbf{b}$ & $18.19 \pm 5.10 \mathbf{a b}$ \\
$20 \mathrm{a}$ & $80.52 \pm 3.67 \mathbf{d}$ & $17.82 \pm 3.33 \mathbf{d}$ & $8.73 \pm 1.61 \mathbf{d}$ & $0.40 \pm 0.04 \mathbf{g}$ & $3.11 \pm 0.58 \mathbf{c d}$ & $4.54 \pm 0.73 \mathbf{a b}$ & $21.7 \pm 4.18 \mathbf{a}$ \\
$\mathrm{CK} 5$ & $77.16 \pm 4.88 \mathbf{d e}$ & $16.94 \pm 6.20 \mathbf{d e}$ & $8.59 \pm 2.30 \mathbf{d e}$ & $0.43 \pm 0.02 \mathbf{f}$ & $2.93 \pm 0.60 \mathbf{d}$ & $4.58 \pm 0.80 \mathbf{a b}$ & $19.96 \pm 1.15 \mathbf{a}$ \\
$\mathrm{CK} 10$ & $67.09 \pm 5.12 \mathbf{e}$ & $14.41 \pm 3.52 \mathbf{e}$ & $7.69 \pm 2.23 \mathbf{e}$ & $0.48 \pm 0.04 \mathbf{e}$ & $2.54 \pm 0.39 \mathbf{e}$ & $4.71 \pm 0.54 \mathbf{a}$ & $16.18 \pm 1.06 \mathbf{b}$ \\
$\mathrm{CK} 20$ & & & & & & &
\end{tabular}

2 Sample size $\mathrm{n}=3$. Value are means \pm standard errors. Upper and lower case indicated significant differences $(P<0.05)$ between treatments.

35 a: Cotton residues have been incorporated for 5 years in long-term continuous cropping cotton field; 10 a: Cotton residues have been incorporated

4 for 5 years in long-term continuous cropping cotton field; 15 a: Cotton residues have been incorporated for 15 years in long-term continuous

5 cropping cotton field; 20 a: Cotton residues have been incorporated for 20 years in long-term continuous cropping cotton field 。

6 


\section{Table 3 (on next page)}

Concentrations of $\mathrm{N}(\mathrm{mg} \mathrm{kg}-1)$ in the various fractions in long-term continuous croppingcotton field under straw incorporation 


\begin{tabular}{ccccccc}
\hline \multirow{2}{*}{ Treatment } & \multicolumn{5}{c}{ Hydrolysable N } & Insoluble N \\
\cline { 2 - 6 } & Amino acid N & Ammonium N & Amino sugar N & Unidentified N & Total N & \\
\hline $5 \mathrm{a}$ & $99.17 \pm 10.11 \mathbf{c}$ & $84.58 \pm 6.90 \mathbf{c}$ & $26.25 \pm 3.86 \mathbf{c d}$ & $138.25 \pm 14.17 \mathbf{c}$ & $348.25 \pm 5.25 \mathbf{c}$ & $160.32 \pm 10.22 \mathbf{c}$ \\
$10 \mathrm{a}$ & $134.17 \pm 5.05 \mathbf{b}$ & $97.71 \pm 2.53 \mathbf{c}$ & $33.54 \pm 5.05 \mathbf{a b}$ & $158.67 \pm 12.75 \mathbf{b}$ & $424.08 \pm 17.56 \mathbf{b}$ & $174.49 \pm 10.31 \mathbf{b}$ \\
$15 \mathrm{a}$ & $122.5 \pm 10.11 \mathbf{b c}$ & $105.00 \pm 7.58 \mathbf{b}$ & $30.63 \pm 7.58 \mathbf{b c}$ & $189.88 \pm 6.97 \mathbf{a}$ & $448.00 \pm 16.33 \mathbf{b}$ & $190.10 \pm 12.28 \mathbf{a b}$ \\
$20 \mathrm{a}$ & $151.67 \pm 10.11 \mathbf{a}$ & $113.75 \pm 4.38 \mathbf{a}$ & $37.33 \pm 3.54 \mathbf{a}$ & $182.58 \pm 15.67 \mathbf{a}$ & $485.33 \pm 12.63 \mathbf{a}$ & $206.57 \pm 12.08 \mathbf{a}$ \\
CK5 & $78.17 \pm 10.31 \mathbf{e}$ & $71.46 \pm 5.05 \mathbf{d}$ & $23.63 \pm 2.87 \mathbf{d e}$ & $104.42 \pm 19.69 \mathbf{d}$ & $277.67 \pm 10.34 \mathbf{e}$ & $123.706 \pm 14.99 \mathbf{d}$ \\
$\mathrm{CK} 10$ & $87.50 \pm 5.52 \mathbf{c d}$ & $80.21 \pm 5.05 \mathbf{c d}$ & $21.88 \pm 4.35 \mathbf{d e}$ & $110.25 \pm 10.67 \mathbf{d}$ & $299.83 \pm 9.02 \mathbf{d e}$ & $129.69 \pm 10.16 \mathbf{d}$ \\
$\mathrm{CK} 20$ & $102.08 \pm 12.39 \mathbf{c}$ & $86.04 \pm 3.65 \mathbf{c}$ & $18.96 \pm 2.53 \mathbf{e}$ & $123.08 \pm 16.88 \mathbf{c d}$ & $330.17 \pm 9.30 \mathbf{c d}$ & $148.88 \pm 5.11 \mathbf{c d}$ \\
\hline
\end{tabular}

1 Sample size $\mathrm{n}=3$. Value are means \pm standard errors. Upper and lower case indicated significant differences $(P<0.05)$ between treatments. 


\section{Table 4 (on next page)}

Correlations between soil organic $\mathrm{N}$ distribution (\%) and $\mathrm{N}$-mineralizing enzymeactivities in the long-term continuous cropping cotton field. 


\begin{tabular}{lll}
\hline & Protease & Urease \\
\hline Amino acid N (\%) & 0.293 & 0.157 \\
Ammonium N (\%) & $-0.784^{*}$ & $-0.909^{* *}$ \\
Amino sugar N (\%) & 0.513 & 0.47 \\
Unidentified N (\%) & 0.346 & 0.608 \\
Insoluble N (\%) & -0.546 & -0.612 \\
Total organic N (\%) & $0.837^{*}$ & $0.854^{*}$ \\
\hline
\end{tabular}

$1 *$ and **: statistically significant at $\mathrm{P}<0.05$ and 0.01 , respectively; 2 
Figure 1

Distribution (\%) of soil organic $\mathrm{N}$ fractions in long-term continuous cropping cotton field under straw incorporation.

AAN, AN, ASN, HUN, AIN

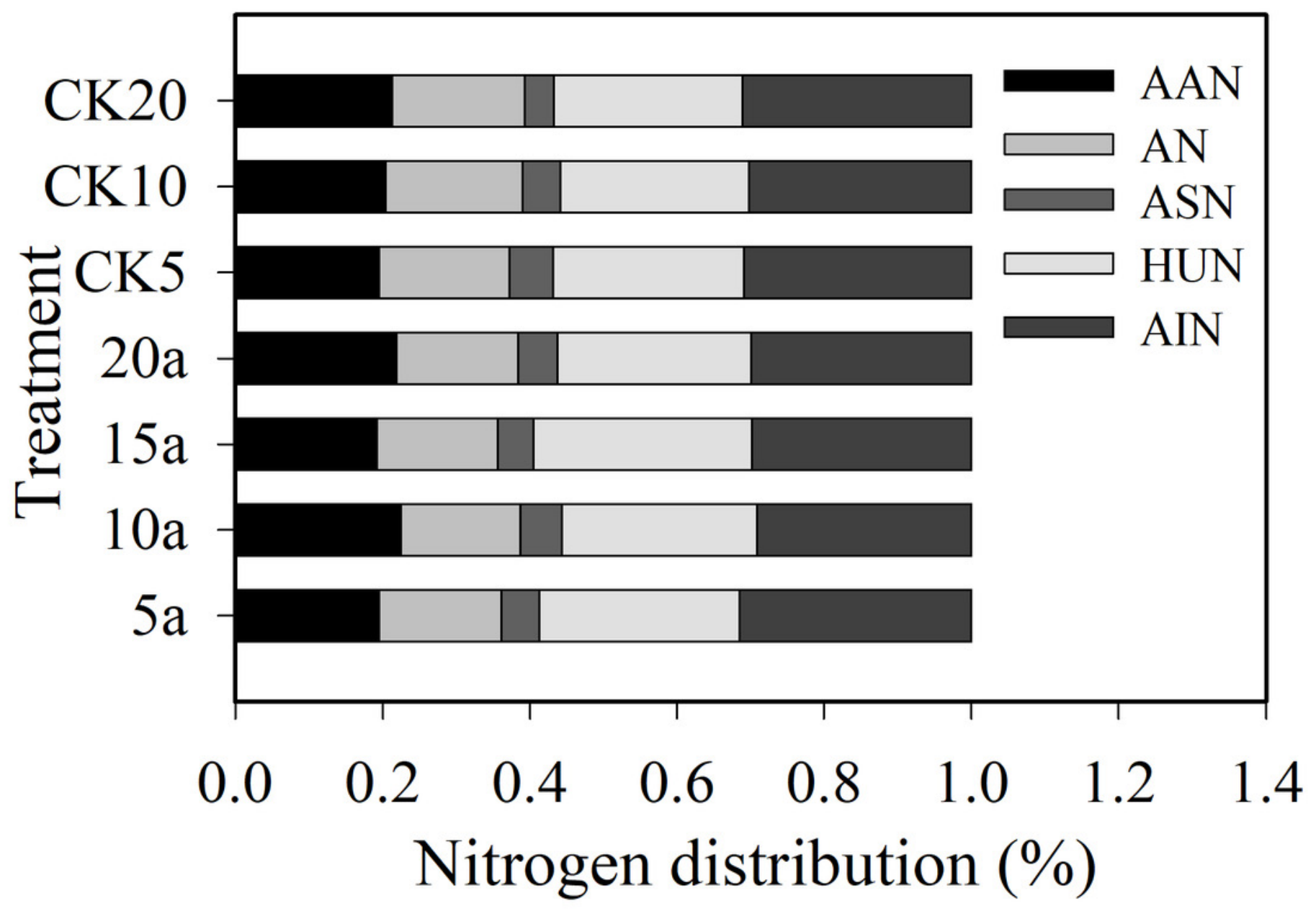


Figure 2

Changes of soil protease activities in long-term continuous cropping cotton field under straw incorporation.

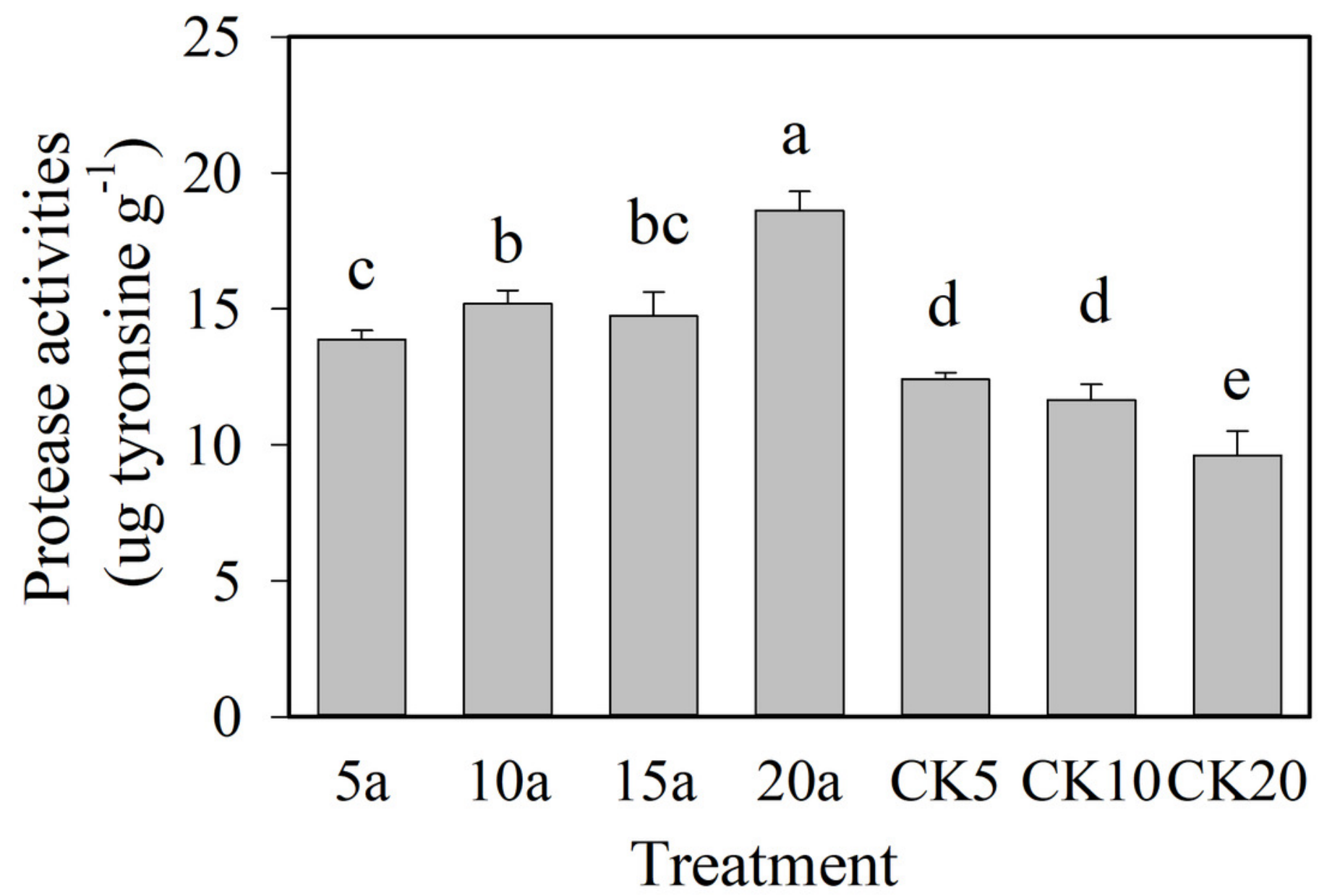


Figure 3

Changes of soil urease activities in long-term continuous cropping cotton field under straw incorporation.

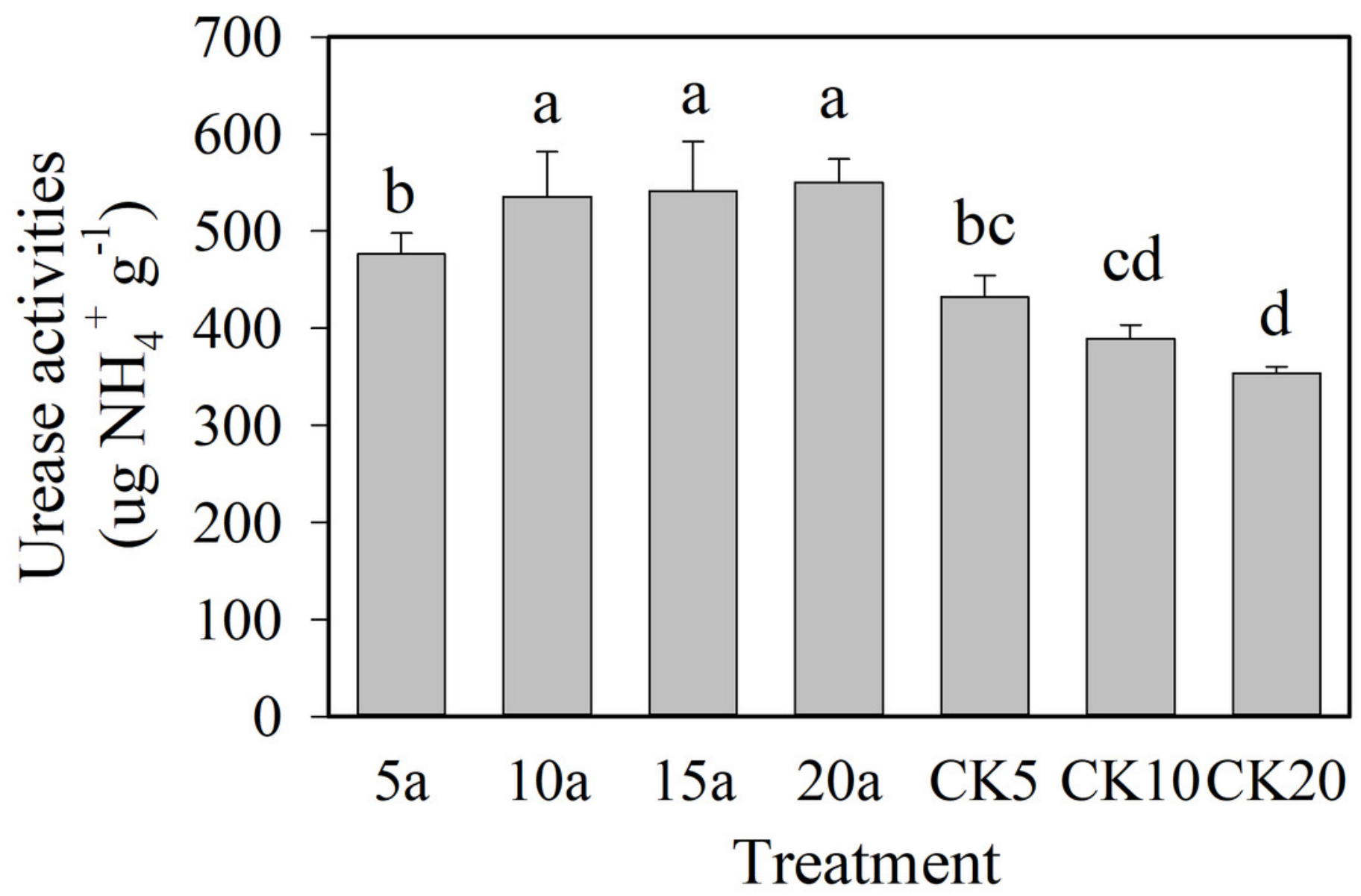

